\title{
THE ROLE OF ULTRASOUND AND LABORATORY METHODS OF STUDYING COMORBID CONDITIONS IN PARKINSON'S DISEASE
}

\author{
Bayborodina I.V.1, Zavadovskaya V.D.2, Zhukova N.G.2, Fetisova T.V.1, \\ Yazhinova V.N. ', Danilenko A.V.' , Basanova A.V.' ', Zangeeva L.A.'
}

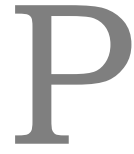

urpose. To study the effect of certain parameters of atherogenesis on the clinical manifestations of Parkinson's disease.

Material and methods. A total of 84 patients were examined: 32 of them with BP and 52 without clinical signs of BP (comparison group). A method of duplex scanning of the extracranial region of the brachiocephalic arteries was applied using a Toshiba 500 ultrasound scanner using a linear sensor with a frequency of $12 \mathrm{MHz}$ (Toshiba Aplio 2010).

Results. As a result of this work, indicators were obtained indicating a lower level of total cholesterol and its fractions, as well as lower values of CMM thickness at the level of the bifurcation of the carotid arteries with a more rare occurrence of atherosclerotic plaques in the lumen of the vessels in the main group, unlike the comparison group. A direct correlation was established between the thickness of the CMI of the carotid arteries at the level of bifurcation on both sides, as well as between the level of LDL cholesterol and total cholesterol.

Analysis of lipid metabolism and intima-media complex thickness in patients with varying degrees of severity of Parkinson's disease on the Hen-Yar scale revealed a statistically significant relationship between total cholesterol in the blood of patients with PD and the degree of motor manifestations of the Henn Yar scale. The maximum concentration of total cholesterol is noted in the mixed (acido-rigid-shivering) form of BP.

Conclusion. Thus, the results of ultrasound and laboratory studies indicate a decrease in atherogenesis in Parkinson's disease, which suggests a decrease in the risk of atherosclerosis in this cohort of patients.

Keywords: parkinson's disease, duplex scanning of the extracranial part of brachiocephalic arteries, atherosclerosis, thickness of intima-media.

Corresponding author: Bayborodina I.V., e-mail: i.baiborodina@mail.ru.

For citation: Bayborodina I.V., Zavadovskaya V.D., Zhukova N.G., Fetisova T.V., Yazhinova V.N., Danilenko A.V., Basanova A.V., Zangeeva L.A. The role of ultrasound and laboratory methods of studying comorbid conditions in parakinson's disease. REJR 2018; 8 (4):23-33. DOI:10.21569/2222-7415-2018-8-4-23-33.

Received: $\quad 15.10 .18 \quad$ Accepted: $\quad 29.10 .18$

\section{РОАЬ УАЬТРАЗВУКОВЫХ И ААБОРАТОРНЫХ МЕТОАОВ ИССАЕАОВАНИЙ КОМОРБИАНЫХ СОСТОЯНИЙ ПРИ БОАЕЗНИ ПАРКИНСОНА}

\section{Байбородина И.В.1 , ЗаваАовская В.А.' 2 , Жукова Н.Г. 2 , Жукова И.А. ${ }^{2}$,} Фетисова Т.В. ' , Яжинова В.Н. ' , Ааниленко А.В. ${ }^{1}$, Басанова А.В. ${ }^{1}$, Зангеева А.А. ${ }^{1}$

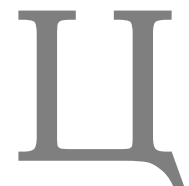

емь исследования. Изучить влияние некоторых параметров атерогенеза на клинические проявления болезни Паркинсона (БП).

Материалы и методы. Обследовано 84 пациента, среди которых было 32 пациента с БП и 52 пациента с хронической ишемией мозга без клинических признаков паркинсонизма (группа сравнения). Применялись дуплексное сканирование экстракраниального отдема брахиоцефальных артерий с использованием ультразвукового сканера Toshiba Aplio 500 (линейный датчик 12 мГц) и определялись показа-

1 - ООО КДЦ «РИТМ». Республика Бурятия, Уиан-Уд, Россия. 2 - Сибирский государственный медицинский университет. Томск, Россия. 
тели мипидного обмена: общий холестерин, мипопротеид низкой плотности (ХС $\Lambda П Н П)$,

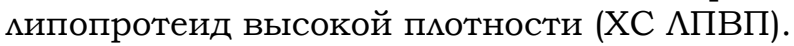

Результаты. В результате проведенной работы получены показатели, свидетельствующие о более низком уровне общего холестерина и его фракции, а также более низкие показатели толщины комплекса интима-медиа (КИМ) на уровне бифуркации сонных артерий, с более редкой встречаемостью атеросклеротических бляшек в просвете сосудов в основной группе в отличие от группы сравнения. Установлена прямая корреляционная связь между толщиной КИМ сонных артерий на уровне бифуркации с обеих сторон, а также между уровнем ХС $\Lambda$ ПП и общим холестерином.

При анализе показателей мипидного обмена и толщины комплекса интима-медиа у пациентов с разцичной степенью тяжести болезни Паркинсона по шкале Хен-Яр выявлена статистически значимая зависимость уровня общего холестерина в крови пациентов с БП и степенью тяжести двигательных проявлений болезни по шкале Хен-Яр. Максимальная концентрация уровня общего холестерина отмечена при смешанной (акинетико-ригидно-дрожательной) форме БП.

Заключение. Результаты ультразвуковых и мабораторных исследований свидетельствуют о снижении показателей атерогенеза при болезни Паркинсона, что позвоцяет говорить о снижении риска развития атеросклероза у данного контингента пациентов.

Ключевые слова: болезнь Паркинсона, дуплексное сканирование экстракраниального отдела брахиоцефальных артерий, атеросклероз, толщина комплекса интимамедиа.

Контактный автор: Байбородина И. В., e-mail: i.baiborodina@mail.ru

Для иитирования: Байбородина И.В., Завадовская В.Д., Жукова Н.Г., Жукова И.А., Фетисова Т.В., Яжинова В.Н., Даниленко А.В., Басанова А.В., Зангеева А.А. Роль ультразвуковых и лабораторных методов исследований коморбидных состояний при болезни паркинсона). REJR 2018; 8 (4):23-33. DOI:10.21569/2222-7415-2018-8-4-23-33.
Статья получена:
15.10 .18
Статья принята:
29.10.18

I $\mathrm{n}$ numerous publications of various authors there are conflicting data on the combination of Parkinson's disease (BP) and atherosclerotic vascular lesions [1, 2, 3, 4, 5, 6, 7]. The study of the possibility of the influence of hyper- and hypocholesterolemia on the debut, the clinical forms and the rates of BP progression are of particular urgency and importance. It is known that the brain is especially rich in cholesterol $(14 \%$ of cholesterol is contained in the white matter of the brain, in gray matter it is $6 \%$ ), therefore any fluctuation in the level of cholesterol and its fractions in the body, as well as a violation of its metabolism (increased formation of low density lipoproteins) to the dysfunction of the membranes of the neurons of the brain and spinal cord, the formation of pathological synaptic transmission and the violation of the synthesis of steroid hormones [4]. Thus, Barcelo-Coblijn G., Golovko M.Y., Weinhofer I. and others (2007) showed the effect of cholesterol in vitro on the level of alphasinuclein and its structure and, conversely, proved the role of alpha-sinuclein in the metabolism of fatty acids in the brain [5]. Moreover, in 2004, scientists proved the relationship of lipid levels with oxidative stress and antioxidant activi- ty, which can explain their role in the pathogenesis of neurodegenerative processes $[6,7]$.

Known markers of atherosclerosis are high levels of total cholesterol (OX), low-density lipoprotein cholesterol (LDL cholesterol), low HDL cholesterol and increased thickness of the inner wall of the vascular wall (intima-media complex (CMM)) at the level of bifurcation of the common carotid artery. In 2000, at the 5th conference of the American Heart Association (AAS) on the prevention of cardiovascular diseases, it was first recommended to determine the thickness of the CMM of the common carotid arteries, as an additional marker for identifying the risk of cardiovascular disease [8]. In one of the works of Russian scientists, data are presented that an increase in the level of OX and LDL cholesterol correlates with the degree of thickening of CMM and the degree of stenosis in the common carotid artery [9]. The method for measuring the thickness of CMM was first described by Paolo Pignoli et al. in 1986, when visualizing the wall of the abdominal aorta [10].

In the process of development of atherosclerosis, the thickening of CMM occurs as a result of migration of a large number of components from the bloodstream to the intima of the arteries: 


\section{RUSSIAN ELECTRONIC JOURNAL OF RADIOLOGY}

monocytes, lymphocytes, cytokines, smooth muscle cells, resulting in the formation of foam cells that are the substrate of atherosclerotic plaque. As a result of the reorganization of cellular elements and the extracellular matrix, the elasticity of the arteries decreases, their stiffness, stiffness develops, the wall thickness/lumen ratio increases, the lumen narrowing, eventually leading to hemodynamically significant obstruction to the blood flow [11].

\section{Introduction.}

Parkinson's disease (BP) is the most common chronic neurodegenerative disease with a predominant lesion of the black substance of the brain, leading to a deficiency of not only dopamine but also other neurotransmitters (serotonin, norepinephrine, glutamate and others) characterized by both pronounced motor and non-motor deficiency and increasing disability. The problems of diagnosis of BP and comorbid (combined) conditions have not lost their significance to the present day and continue to be the focus of attention of physicians of various specialties [12].

Since BP is the lot of elderly people, it is very common for this patient population to have an atherosclerotic lesion of the cerebral vessels leading to chronic cerebral ischemia [13]. In everyday practice, doctors tend to deal with a combination of neurodegenerative diseases and cerebrovascular disorders in the elderly, which makes it difficult to differentiate between the clinical manifestations of the underlying and "secondary" disease in a particular patient and can lead to not always valid therapeutic tactics [14]. In the literature, the possibility of the influence of hyper- and hypocholesterolemia both on the development and on the progression of BP was repeatedly discussed. The mechanism of the influence of lipids remains insufficiently studied. It is known that the brain is especially rich in cholesterol $14 \%$ of cholesterol is contained in the white matter of the brain, in gray matter it is $6 \%$ ), therefore any fluctuation in the level of cholesterol and its fractions in the body, as well as a violation of its metabolism (increased formation of low density lipoproteins) to the dysfunction of the membranes of the neurons of the brain and spinal cord, the formation of pathological synaptic transmission and the violation of the synthesis of steroid hormones [4]. Atherosclerotic lesions of the cerebral vessels are not found in all patients with BP, but they have the following changes in this disease: thinning of the capillary basement membrane, pericyte damage, collagen deposition, damage to endothelial cells, thickening of the inner wall of the vessel wall, sclerosis and thinning of the muscular membrane of the inner carotid artery [17]. As a result of vascular lesions, lacunar infarcts and changes in the type of leukoareosis, found in $1 / 3$ of patients with $\mathrm{BP}$, are formed in the brain [18]. With BP for a long time, the deficit of dopamine can be compensated by the enhancement of its synthesis by intact neurons, which should be ensured by adequate supply of cells with certain chemicals and energy [19]. Progressive impairment of blood circulation in the brain can worsen these compensatory abilities. In addition, it can lead to an increase in the available age-related extrapyramidal insufficiency, which simulates some manifestations of $\mathrm{BP}$, or contribute to the onset of BP [20].

To date there is a large number of publications devoted to the study of the thickness of CMM in the carotid artery with BP [21, 22, 23]. Some of them say that the thickness of CMM was greater in patients with BP than in the control group and that atherosclerotic changes found in patients with PD showed moderate carotid arteries with the most stable calcified plaques, despite a higher degree of stenosis carotid artery in patients with vascular parkinsonism [21,22]. Other studies have data that the thickness of CMM was less in patients with BP and these results indicate that they have a lower risk of developing atherosclerosis [23]. None of the literature publications have data on how these changes depend on the stage and clinical form of BP, and whether the atherosclerotic lesions of the cerebral vessels affect the course and prognosis of this disease.

The purpose of this work was to study the effect of certain parameters of atherogenesis on the clinical manifestations of Parkinson's disease.

Materials and methods.

A total of 84 people were examined: 32 patients with clinically verified diagnosis of BP and 52 with chronic cerebral ischemia without clinical signs of parkinsonism (group-analysis). The age of the subjects ranged from 46 to 80 years, the average age for the main group was $63.6 \pm 8.7$ years, for the comparison group $63.2 \pm 10$ years. All patients were on examination and treatment in $\mathrm{OOO}$ Consultative and Diagnostic Center "RITM", UlanUde (general director - L.A. Zangeeva, chief doctor - A.V. Basanova).

Criteria for inclusion in the main group:

1. Men and women between the ages of 46 and 80 with a diagnosis of BP not taking statins and not suffering from diabetes.

2. The availability of voluntary informed consent for the study.

Exclusion criteria from the main group:

1. Patients with an established diagnosis of $\mathrm{BP}$, taking the drug.

2. The presence of clinical or anamnestic data in patients with BP, stroke, transient ischemic attacks, chronic cerebral ischemia, acute coronary syndrome or high blood glucose levels.

3. Refusal of the patient to participate in the study.

Criteria for inclusion in the comparison group:

1. Men and women aged 46 to 80 years who were outpatient for chronic cerebral ischemia and 


\section{RUSSIAN ELECTRONIC JOURNAL OF RADIOLOGY}

without clinical symptoms of parkinsonism and who do not take statins

2. The availability of voluntary informed consent for the study.

Exclusion criteria from the comparison group:

1. Patients taking the drug.

2. Patients have clinical or anamnestic data of a stroke, transient ischemic attacks, acute coronary syndrome or high blood glucose levels. study.

3. Refusal of the patient to participate in the

All subjects underwent general osmotic and neurological examination.

Duplex scanning of the extracranial region of the brachiocephalic system was performed using the Toshiba Aplio 500 digital diagnostic ultrasound system (Toshiba Medical Systems Corporation, Japan, 12-MHz linear sensor) using additional options (Precision Imaging Apli Pure TM and Speckle Reduction) that contribute to a more accurate definition of the thickness of CMM and, therefore, the diagnostic value of the duplex scanning method of the extracranial department of the brachiocephalic system [14]. According to the national recommendations that were developed by the Expert Committee of the All-Russian Scientific Society of Cardiology (2011), Kim thickness is considered to be increased if it is equal to or greater than 1.1 millimeters $(\mathrm{mm})$. Local thickening of CMM more than $1.3 \mathrm{~mm}$ indicates the presence of an atherosclerotic plaque [24] (Fig. 1, 2).

Laboratory examination was carried out according to general rules. Blood sampling for determination of lipid metabolism - total cholesterol, low density lipoprotein (LDL cholesterol), high density lipoprotein (HDL cholesterol) was carried out after a preliminary 12-hour fasting with the photometric colorimetry method [25]. Normal is the value of the concentration of total cholesterol in the blood for people over 40 years old, 3.63$5.20 \mathrm{mmol} / 1$. The concentration of total cholesterol above $6.5 \mathrm{mmol} / 1$ is considered a risk factor for the development of atherosclerosis. The normal values of the concentration of cholesterol in the blood serum for people over 40 years are: for women $0.78-2.2 \mathrm{mmol} / 1$, for men $0.78-1.8$ $\mathrm{mmol} / 1$. The decrease in the concentration of HDL cholesterol is lower than $0,9 \mathrm{mmol} / 1$ is associated with an increased risk of developing atherosclerosis. Admissible limits for adult LDL cholesterol in the serum are $1.68-4.53 \mathrm{mmol} / 1$ [26].

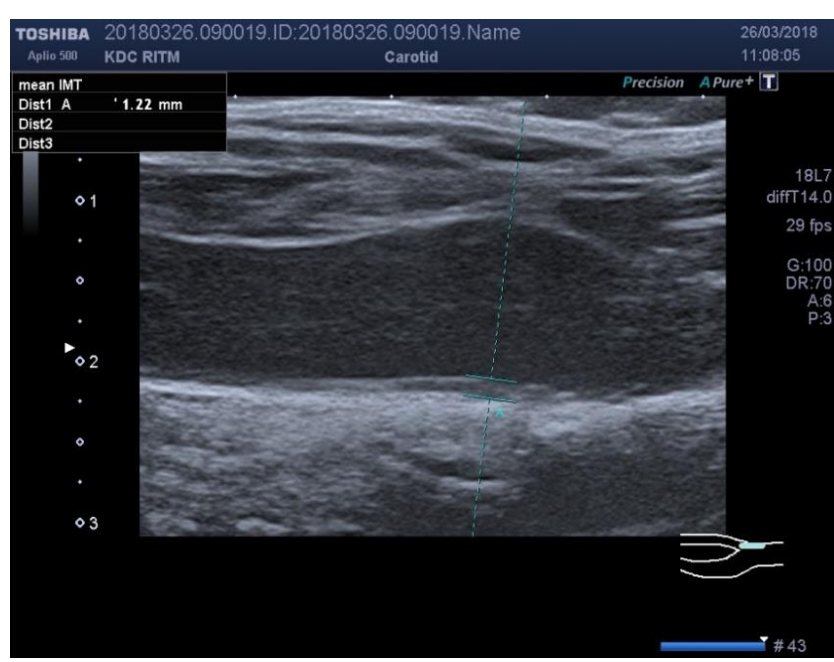

Fig. 1 (Рис. 1)

Fig. 1. Sonogram.

The image of the thickened part of the intima-media complex at the level of bifurcation of the common carotid artery (thickness of $\mathrm{CMM}=1.22 \mathrm{~mm}$ ).

\section{Рис. 1. Сонограмма.}

Изображение утолщенного участка комплекса интима-медиа на уровне бифуркации общей сонной артерии (толщина КИМ = 1.22 мм).

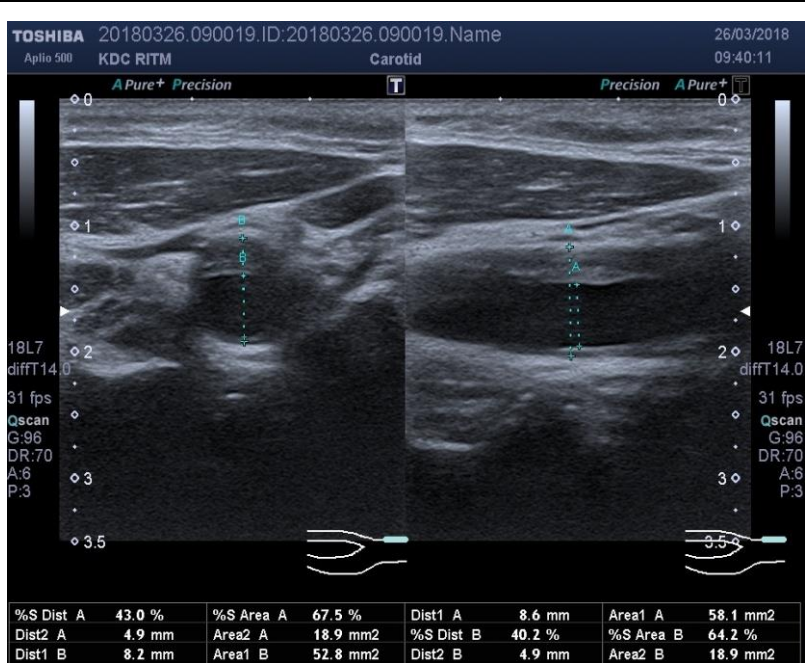

Fig. 2 (Рис. 2)
Fig. 2. Sonogram.

The image of an atherosclerotic plaque at the bifurcation level of the common carotid artery (left-transverse section of the atherosclerotic plaque stenosing the lumen of the common carotid by $43 \%$; right-longitudinal section of the atherosclerotic plaque stenosing the lumen of the common carotid by $40 \%$ ).

\section{Рис. 2. Сонограмма.}

Изображение атеросклеротической бляшки на уровне бифуркации общей сонной артерии (left - поперечный срез атеросклеротической бляшки, стенозирующей просвет общей сонной артерии на 43\%; right - продольный срез атеросклеротической бляшки, стенозирующей просвет общей сонной артерии на $40 \%$ ). 
Table №1. Indicators of lipid metabolism, thickness of CMM and the presence of intraluminal formations (atherosclerotic plaques) in patients of the main group and the comparison group.

\begin{tabular}{|l|l|l|l||}
\hline Index & Main group & $\begin{array}{l}\text { Comparison group } \\
\text { (CHIM without signs } \\
\text { of parkinsonism }) \\
(\mathrm{n}=52)\end{array}$ & \\
\hline Age & $(\mathrm{n}=32)$ & 63,2 & 0,900956 \\
\hline Total cholesterol, mmol / 1 & 63,6 & $6,1 \pm 1,1$ & 0,0000 \\
\hline Level HCLP, mmol / 1 & $4,8 \pm 1.2$ & $3,5 \pm 1,3$ & 0,000049 \\
\hline Level of HDL cholesterol, mmol / 1 & 1,2 & 1,2 & 0,141841 \\
\hline Thickness CMM on the right, mm & 1,0 & $(1,0-1,3)$ & 0,003623 \\
\hline formations & $(0,8-1,2)$ & 1,2 & 0,000336 \\
\hline Thickness of CMM on the left, mm & 1,0 & $(0,85-1,3)$ & \\
\hline
\end{tabular}

The statistical analysis was carried out using the SPSS 17.0 software package. The quantitative data reporting to the normal distribution was described by calculating the mean $(\mathrm{X})$ with the standard deviation $(\mathrm{m})$, those data that do not obey the normal distribution law were described with the median (Me) and the interquartile range

(Q1-Q3). The test for compliance with the normal distribution law was carried out by the Shapiro-Wilk criterion. To assess the reliability of the differences in the data, Student's t-test was used, and the Mann-Whitney test. To assess the reliability of the differences in qualitative data the $\mathrm{x} 2$ criterion or the exact Fisher criterion. To estimate the reliability of the differences in quantitative data, dispersion analysis and the CraskellWallis criterion were used. The relationship of the symptoms was evaluated by calculating the rank correlation coefficient of Spearman (r). The critical level of significance in testing statistical hypotheses was assumed to be 0.05 .

Results and discussion. At the first stage of the work, a comparative analysis of the level of total cholesterol, LDL cholesterol, HDL cholesterol, the thickness of the CIM extracranial section of brachiocephalic vessels on both sides of the inci- dence of intraluminal vascular formations (atherosclerotic plaques) in patients with BP and patients of the comparison group (Table 1) was carried out.

The data presented in Table. 1, showed a lower level of total cholesterol and its fraction of LDL-XL in the main group, in contrast to the comparison group, which had statistically significant differences $(4.8 \pm 1.2 \mathrm{mmol} / \mathrm{L}$ and $6.1 \pm 1.1$ $\mathrm{mmol} / \mathrm{L}$ at $\mathrm{p}<0.05,2.7 \pm 0.8 \mathrm{mmol} / \mathrm{L}$, and $3.5 \pm$ $1.3 \mathrm{mmol} / \mathrm{L}$ at $\mathrm{p}<0.05$, respectively) and agrees with earlier findings of other authors $[16,27]$. In addition, in the main group, lower CMM thickness values were recorded at the level of bifurcation of carotid arteries, and the occurrence of atherosclerotic plaques in the lumen of vessels was less often noted, which also had statistically significant differences from the comparison group values $(\mathrm{p}$ $<0.05)$. Thus, atherosclerotic plaques were record 


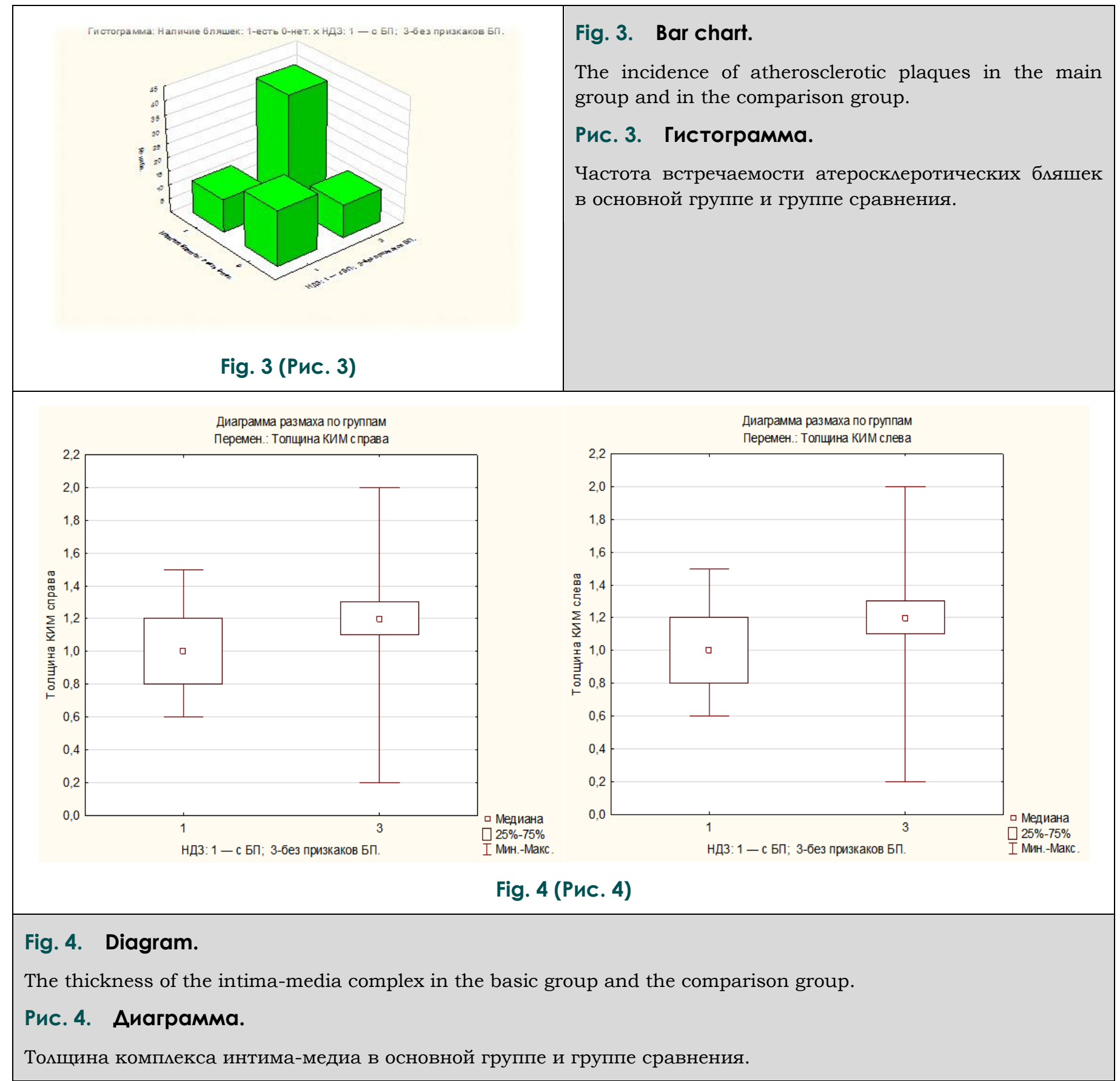

ed 2.05 times more often in patients of the comparison group, which may indicate a lower level of atherogenesis in BP patients (Fig. 3, 4).

In our study, there were no statistically significant differences between the levels of HDL cholesterol in patients of both groups: in the patients of the main group this level was 1.2 (1.1-1.5) $\mathrm{mmol} / 1$, and in the comparison group $1.2(1.0-1.3)$ $\mathrm{mmol} / 1$ ( $\mathrm{p}>0.05)$.

Next, a rank correlation analysis of the studied indicators in the surveyed groups was conducted (Table 2, 3).

The data obtained indicate that patients with BP have a direct correlation between total cholesterol and HDL cholesterol $(\mathrm{R}=0.419876, \mathrm{p}$ $=0.016)$ and LDL cholesterol $(\mathrm{R}=0.545171, \mathrm{p}=$ $0.012)$ and between LDL cholesterol and HDL cholesterol $(\mathrm{R}=0.566824, \mathrm{p}=0.007)$.
The correlation analysis of the studied parameters in the patients of the comparison group revealed a direct correlation between the thickness of the carotid CMM at the bifurcation level on both sides $(\mathrm{R}=0.8944, \mathrm{p}=0.0000)$, and also between the level of LDL cholesterol and total cholesterol $(\mathrm{R}=0,548,259, \mathrm{p}=0.0000)$.

The comparison of lipid metabolism and the results of duplex scanning of brachiocephalic arteries in patients with BP depending on the severity of the condition on the Hen-Yar scale are presented in Table 4.

For the implementation of this stage of the study, all patients were divided into the following groups, depending on the degree of motor impairment: Stage I by Hen-Yar (hemiparkinsonism, more often tremor, patients, as a rule, do not notice difficulty in moving and performing daily 
RUSSIAN ELECTRONIC JOURNAL OF RADIOLOGY

Table №2. Results of correlation analysis of age, lipid metabolism and thickness of intima-media complex in patients with Parkinson's disease.

\begin{tabular}{|c|c|c|c|c|c|c|}
\hline & Age & $\begin{array}{l}\text { Thickness of } \\
\text { CMM on the } \\
\text { left }\end{array}$ & $\begin{array}{l}\text { CMM thickness } \\
\text { on the right }\end{array}$ & $\mathbf{O H}$ & HDL & LDL \\
\hline Age & 1,000000 & 0,286050 & 0,286050 & $\begin{array}{l}- \\
0,0305 \\
84\end{array}$ & $\begin{array}{l}0,15038 \\
4\end{array}$ & 0,029882 \\
\hline $\begin{array}{l}\text { Thickness of CMM } \\
\text { on the left }\end{array}$ & 0,286050 & 1,000000 & 1,000000 & $\begin{array}{l}0,1160 \\
63\end{array}$ & $\begin{array}{l}0,12951 \\
5\end{array}$ & 0,295843 \\
\hline $\begin{array}{l}\text { CMM thickness on } \\
\text { the right }\end{array}$ & 0,286050 & 1,000000 & 1,000000 & $\begin{array}{l}0,1160 \\
63\end{array}$ & $\begin{array}{l}0,12951 \\
5\end{array}$ & 0,295843 \\
\hline Total cholesterol & $-0,030584$ & 0,116063 & 0,116063 & $\begin{array}{l}1,0000 \\
00\end{array}$ & $\begin{array}{l}0,41987 \\
6\end{array}$ & 0,545171 \\
\hline HDL cholesterol & 0,150384 & 0,129515 & 0,129515 & $\begin{array}{l}0,4198 \\
76\end{array}$ & $\begin{array}{l}1,00000 \\
0\end{array}$ & 0,566824 \\
\hline LDL cholesterol & 0,029882 & 0,295843 & 0,295843 & $\begin{array}{l}0,5451 \\
71\end{array}$ & $\begin{array}{l}0,56682 \\
4\end{array}$ & 1,000000 \\
\hline
\end{tabular}

Table №3. Results of correlation analysis of age, lipid metabolism and thickness of intima-media complex in patients of the comparison group.

\begin{tabular}{|l|l|l|l|l|l|l|l|}
\hline & Age & $\begin{array}{l}\text { Thickness } \\
\text { CMM of } \\
\text { left }\end{array}$ & $\begin{array}{l}\text { of } \\
\text { the }\end{array}$ & $\begin{array}{l}\text { CMM thickness on } \\
\text { the right }\end{array}$ & OH & HDL & LDL \\
\hline Age & 1,000000 & $\mathbf{0 , 4 5 5 8 5 6}$ & $\mathbf{0 , 4 4 6 1 6 2}$ & $\begin{array}{l}\mathbf{0 , 3 5 4} \\
\mathbf{4 6 2}\end{array}$ & $-0,080121$ & $\begin{array}{l}0,25792 \\
2\end{array}$ \\
\hline \begin{tabular}{l|l|l|l|l|l|l|}
\hline Thickness of CMM \\
on the left
\end{tabular} & $\mathbf{0 , 4 5 5 8 5 6}$ & 1,000000 & $\mathbf{0 , 8 9 6 8 4 4}$ & $\begin{array}{l}0,257 \\
919\end{array}$ & 0,013622 & $\begin{array}{l}0,19704 \\
0\end{array}$ \\
\hline $\begin{array}{l}\text { CMM thickness on } \\
\text { the right }\end{array}$ & $\mathbf{0 , 4 4 6 1 6 2}$ & $\mathbf{0 , 8 9 6 8 4 4}$ & 1,000000 & $\begin{array}{l}0,243 \\
552\end{array}$ & $-0,057946$ & $\begin{array}{l}0,17619 \\
9\end{array}$ \\
\hline Total cholesterol & $\mathbf{0 , 3 5 4 4 6 2}$ & 0,257919 & 0,243552 & $\begin{array}{l}1,000 \\
000\end{array}$ & 0,159484 & $\begin{array}{l}\mathbf{0 , 5 4 8 2 5} \\
\mathbf{9}\end{array}$ \\
\hline HDL cholesterol & $-0,080121$ & 0,013622 & $-0,057946$ & $\begin{array}{l}0,159 \\
484\end{array}$ & 1,000000 & $\begin{array}{l}0,08362 \\
9\end{array}$ \\
\hline LDL cholesterol & 0,257922 & 0,197040 & 0,176199 & $\begin{array}{l}\mathbf{0 , 5 4 8} \\
\mathbf{2 5 9}\end{array}$ & 0,083629 & $\begin{array}{l}1,00000 \\
0\end{array}$ \\
\hline
\end{tabular}


The remaining analyzed parameters in pa-

Table №4. Indicators of lipid metabolism, thickness of the intima-media complex in patients with varying severity of Parkinson's disease according to the Hen-Yar scale.

\begin{tabular}{|c|c|c|c|c|c|}
\hline Index & Stage I $(n=11)$ & II stage $(n=14)$ & III stage $(n=7)$ & $\begin{array}{l}\text { Ranked YES } \\
\text { Kraskela- } \\
\text { Wallis (H) }\end{array}$ & $\mathrm{p}$ \\
\hline $\begin{array}{l}\text { Total cholesterol, } \\
\mathrm{mmol} / \mathrm{l} \text {. }\end{array}$ & $4,8 \pm 1,2$ & $5,1 \pm 1,1$ & $4,1 \pm 0,9$ & 6,233858 & 0,0443 \\
\hline $\begin{array}{l}\text { LDL cholesterol } \\
\text { level, } \mathrm{mmol} / \mathrm{l} \text {. }\end{array}$ & $2,6 \pm 0,9$ & $2,9 \pm 0,8$ & $2,7 \pm 0,9$ & 0,2759904 & 0,8711 \\
\hline $\begin{array}{l}\text { Level of HDL cho- } \\
\text { lesterol, mmol / } 1 .\end{array}$ & $\begin{array}{l}1,1 \\
(1,0-1,5)\end{array}$ & $\begin{array}{l}1,2 \\
(1,2-1,8)\end{array}$ & $\begin{array}{l}1,1 \\
(1,1-1,2)\end{array}$ & 2,853180 & 0,2401 \\
\hline $\begin{array}{l}\text { Thickness CMM } \\
\text { on the right, } \mathrm{mm}\end{array}$ & $\begin{array}{l}0,9 \\
(0,6-1,1)\end{array}$ & $\begin{array}{l}1 \\
(0,8-1,3)\end{array}$ & $\begin{array}{l}0,9 \\
(0,9-1,1)\end{array}$ & 1,479273 & 0,4773 \\
\hline $\begin{array}{l}\text { Thickness of CMM } \\
\text { on the left, mm }\end{array}$ & $\begin{array}{l}0,9 \\
(0,6-1,1)\end{array}$ & $\begin{array}{l}1 \\
(0,8-1,3)\end{array}$ & $\begin{array}{l}0,9 \\
(0,9-1,1)\end{array}$ & 1,479273 & 0,4773 \\
\hline
\end{tabular}

Note: The significance criteria for $\mathrm{p}<0.05$

tasks) - 11 people, II stage (symptoms of parkinsonism have a bilateral character without an equilibrium disorder, pronounced hypokinesia, speech disturbance, gait) - 14 people and stage III (mild or moderate imbalance, instability in walking or standing iy, difficulties in tearing the foot off the ground, but the patients do not need help and are able to serve themselves without any problems) - 7 people. In our study there were no patients with IV and V stages of the BP in Hen-Yar (gross manifestations of Parkinsonism with severe symptoms of imbalance, such patients need constant external help).

From the data in the table it follows that the total cholesterol values were within reference values (3.63-5.20 mmol/1) in patients with BP. Moreover, the maximum values of total cholesterol were registered at the II stage of the BP according to Hen-Yar $(5.1 \pm 1.1 \mathrm{mmol} / \mathrm{l})$, whereas a significant decrease in the total cholesterol content was noted at the III stage of BP by Hen-Yar (3.8 $\pm 0,7$ $\mathrm{mmol} / 1)$.

Therefore, we can speak of a statistically significant relationship between the total cholesterol level in the blood of patients with BP and the severity of the motor manifestations of the disease according to Hen-Yar $(\mathrm{H}=6.233858, \mathrm{p}=0.0443)$. tients with BP were within reference values and did not have statistically significant differences.

The next stage of the work consisted in the study of the level of total cholesterol, LDL cholesterol, HDL cholesterol and thickness of CMM depending on different clinical forms of BP (Table 5).

The analysis of the data presented in the table showed that the maximum concentration of the total cholesterol level was noted with a mixed (akinetic-rigid-shaking) form of BP (5.0 \pm 1.4 $\mathrm{mmol} / \mathrm{l})$. At the same time, the minimum level of LDL cholesterol $(2.6 \pm 0.1 \mathrm{mmol} / 1)$. However, there were no statistically significant differences between the clinical groups for all analyzed lipid metabolism parameters and duplex scanning of brachiocephalic arteries.

The final stage of the study was an analysis of the incidence of atherosclerotic plaques in patients of the main group at different stages of BP and in different clinical forms of BP (Table 6, 7).

The data of Tables 6 and 7 show that there are no statistically significant differences in the occurrence of atherosclerotic plaques at various stages according to Hen-Yar in BP (X2 = 0.016, p $=0.99)$ and in different clinical forms of BP (X2 = 3.854; $p=0,14)$.

Conclusion. 
Table №5. The parameters of lipid metabolism, the thickness of the intima-media complex in patients with various clinical forms of Parkinson's disease.

\begin{tabular}{|c|c|c|c|c|c|}
\hline Index & $\begin{array}{l}\text { Akinetic-rigid } \\
\text { form of } \mathrm{BP} \\
(\mathrm{n}=12)\end{array}$ & $\begin{array}{l}\text { Throbbing } \\
\text { form of BP } \\
(n=6)\end{array}$ & $\begin{array}{l}\text { Mixed form } \\
\text { of } \mathrm{BP}(\mathrm{n}=14)\end{array}$ & $\begin{array}{l}\text { Ranked YES } \\
\text { Kraskela-Wallis } \\
(\mathrm{H})\end{array}$ & $\mathrm{p}$ \\
\hline $\begin{array}{l}\text { Total cholesterol, } \\
\mathrm{mmol} / \mathrm{l}\end{array}$ & $4,5 \pm 1,0$ & $4,6 \pm 0,5$ & $5,0 \pm 1,5$ & 1,399363 & 0,4967 \\
\hline $\begin{array}{l}\text { LDL cholesterol } \\
\text { level, mmol/l }\end{array}$ & $2,9 \pm 0,8$ & $2,9 \pm 0,5$ & $2,6 \pm 0,1$ & 1,145176 & 0,5641 \\
\hline $\begin{array}{l}\text { Level of HDL cho- } \\
\text { lesterol, } \mathrm{mmol} / \mathrm{l}\end{array}$ & $\begin{array}{l}1,2 \\
(1,1-1,55)\end{array}$ & $\begin{array}{l}1,4 \\
(1,2-1,6)\end{array}$ & $\begin{array}{l}1,15 \\
(1,1-1,47)\end{array}$ & 1,605484 & 0,4481 \\
\hline $\begin{array}{l}\text { Thickness } \mathrm{CMM} \\
\text { on the right, } \mathrm{mm}\end{array}$ & $\begin{array}{l}1,0 \\
(0,7-1,2)\end{array}$ & $\begin{array}{l}0,8 \\
(0,7-0,9)\end{array}$ & $\begin{array}{l}1,0 \\
(0,8-1,2)\end{array}$ & 2,553084 & 0,2790 \\
\hline $\begin{array}{l}\text { Thickness of CMM } \\
\text { on the left, } \mathrm{mm}\end{array}$ & $\begin{array}{l}1,0 \\
(0,7-1,2)\end{array}$ & $\begin{array}{l}0,8 \\
(0,7-0,9)\end{array}$ & $\begin{array}{l}1,0 \\
(0,8-1,2)\end{array}$ & 2,553084 & 0,2790 \\
\hline
\end{tabular}

Note: The significance criteria for $\mathrm{p}<0.05$.

Table №6. Indices of incidence of intraluminal formations in patients at different stages of Parkinson's disease.

\begin{tabular}{|l|l|l|l|l|l|l|l|}
\hline Index & $\begin{array}{l}\text { 1st stage in } \\
\text { Hen-Yar } \\
(\mathrm{n}=11)\end{array}$ & $\begin{array}{l}\text { II stage in } \\
\text { Hen-Yar } \\
\text { (n=14) }\end{array}$ & $\begin{array}{l}\text { III stage in } \\
\text { Hen-Yar } \\
\text { (n=7) }\end{array}$ & $\begin{array}{l}\text { Pearson } \\
\text { Chi- } \\
\text { square }\end{array}$ & $\mathrm{p}$ & $\begin{array}{l}\text { MP Chi- } \\
\text { square }\end{array}$ & $\mathrm{p}$ \\
\hline $\begin{array}{c}\text { The presence of in- } \\
\text { traluminal vascular } \\
\text { formations (athero- } \\
\text { sclerotic plaques) }\end{array}$ & 4 & 5 & 2 & $\begin{array}{l}0,0161 \\
649\end{array}$ & $\begin{array}{l}0,991 \\
95\end{array}$ & $\begin{array}{l}0,016267 \\
0\end{array}$ & 0,9919 \\
0
\end{tabular}


Table №7. Indices of incidence of intraluminal formations in patients with different clinical forms of Parkinson's disease.

\begin{tabular}{|c|c|c|c|c|c|c|c|}
\hline Index & \begin{tabular}{l}
\multicolumn{2}{l}{ Akinetic- } \\
rigid form \\
of $\quad B P$ \\
$(n=12)$
\end{tabular} & $\begin{array}{l}\text { Throbbing } \\
\text { form of BP } \\
(n=6)\end{array}$ & $\begin{array}{l}\text { Mixed form } \\
\text { of } \quad \text { BP } \\
(n=14)\end{array}$ & $\begin{array}{l}\text { Pears } \\
\text { on } \\
\text { Chi- } \\
\text { square }\end{array}$ & $\mathrm{p}$ & $\begin{array}{l}\text { MP } \\
\text { Chi- } \\
\text { square }\end{array}$ & $\mathrm{p}$ \\
\hline $\begin{array}{l}\text { The presence of in- } \\
\text { traluminal vascular } \\
\text { formations (athero- } \\
\text { sclerotic plaques) }\end{array}$ & 6 & 0 & 5 & $\begin{array}{l}3,854 \\
870\end{array}$ & 0,14552 & $\begin{array}{l}5,439 \\
504\end{array}$ & $\begin{array}{l}0,065 \\
89\end{array}$ \\
\hline
\end{tabular}

After examining the results of ultrasound and laboratory studies suggesting a decrease in the rates of atherogenesis in Parkinson's disease, it can be assumed that in this contingent of patients the risk of atherosclerosis is lower and they are less susceptible to the occurrence of vascular diseases of the brain, such as chronic ischemia or stroke of the brain.

Source of funding and conflict of interest.

The authors of this article confirmed the lack of financial support for research and conflict of interests, which need to be reported.

\section{References:}

1. Scigliano G, Musicco M, Soliveri P. et al. Reduced risk factors for vascular disorders in Parkinson disease patients: a casecontrol study. Stroke. 2006; 37 (5): 1184-1188.

2. Reiss B, Siller K.A., Rahman M.M. et al. Cholesterol in neurologic disorders of the elderly: stroke and Alzheimer's disease. Neurobiology of Aging. 2004; 25 (8): 977-989.

3. Folstein M.F., Folstein S.E., McHugh P.R. Mini-mental status $J$ Psychiatr Res. 1975; 12:189-196.

4. Lau L.M., Breteler M.M.B. Epidemiology of Parkinson's disease. Lancet Neurol. 2006; 5: 525-535

5. Huang X, Alonso A, Guo X et al. Statins, plasma cholesterol, and risk of Parkinson's disease: A prospective study. Mov Disord. 2015; 30: 552-559.

6. Hu G, Antikainen R, Jousilahti P et al. Total cholesterol and the risk of Parkinson disease. Neurology.2008; 70: 1972-1979.

7. Vasilenko A.F., Shamurov U.S. Lipid metabolism in Parkinson's disease. Journal of Neuroscience and Psychiatry named after S. Korsakov 2012; 112: 7: 65-67 (in Russian).

8. Stein J.H., Korcarz C.E., Hurst R.T., et al. Use of carotid ultrasound to identify subclinical vascular disease and evaluate cardiovascular disease risk: a consensus statement from the American Society of Ehocardiography Carotid Intima-Media Thickness Task Force. Endorsed by the Society for Vascularmedicine. J. Am. Soc. Echocardiogr. 2008; 21: 93-111.

9. Kindayshova V.V., Tihomirova O.V., Zybina N.N., Kozhevnikova O.V., Vasil,ev V.N. Journal of the All-Russian Center for Emergency and Radiation Medicine. A.M. Nikiforova EMERCOM of Russia. 2014, 4: 53-56 (in Russian).

10. Pignoli P, Tremoli E, Poli A, et al. Intimal plus medial thickness of the arterial wall: a direct measurement with ultrasound imaging. Circulation 1986; 74: 1399-406.

11. Katamadze N.O., Bershtein L.L., Grishkin YU.N Diagnosis of

subclinical atherosclerosis as an element of the modern stratification strategy of cardiovascular risk. Cardiovascular therapy and prevention, 2012; 11 (2): C 76-84 (in Russian).

12. Zhukova I.A., Zhukova N.G., Izhboldina O.P., Nikitina M.A., Aliphirova V.M. Analysis of methods for assessing olfaction in patients with Parkinson's disease. Journal of Neurology and Psychiatry. S.S. Korsakov. Issue 2: Neurology and psychiatry of the elderly, 2015. P. 47-52 (in Russian).

13. Gusev E.I., Skvorcova V.I. Ischemia of the brain. M: Medicine 2001; 328 p. (in Russian).

14. Makarov N.S., Spiridonova S.V., Nikitina V.V., Voskresenskaya O.N., Zakharova N.B. Molecular markers of endothelial damage in patients with Parkinson's disease. Saratov Scientific Medical Journal. 2006; 2: 3: 29-33 (in Russian).

15. Bar-On P, Rockenstein E, AdameA et al. Effects of the cholesterol-lowering compound methyl- $\beta$-cyclodextrin in models of asynucleinopathy. Journal of Neurochemistry. 2006; 98 (4): 1032 1045.

16. Gutorova D.A., Vasenina E.D., Vasenina E.E., Levin O.S. Is hyperlipidemia a risk factor for Parkinson's disease? Journal of Neurology and Psychiatry. S.S. Korsakov. 2015; 115 (6) (in Russian).

17. Resveratrol preserves cerebrovascular density and cognitive function in aging mice Charlotte A. Oomen, EszterFarkas, Viktor Roman, Eline M. van der Beek, Paul G. M. Luiten and Peter Meerlo.

18. Letvinenko I.V. Parkinson's disease. M., Miklosh, 2006. 216 p. (in Russian).

19. Golubev V.L. Levin YA.I., Vein A.M. Parkinson's disease and Parkinson's syndrome. M., MEDPress, 1999. P. 41-48 (in Russian).

20. Kryzhanovskii G.N., Karaban I.N., Magaeva S.V., Ku- 


\section{RUSSIAN ELECTRONIC JOURNAL OF RADIOLOGY}

cheryanu V.G., Karaban N.V. Parkinson's disease (etiology, pathogenesis, clinic, diagnosis, treatment, prevention). M., Medicine, 2002. 336 p. (in Russian).

21. Bradvica IS1, Janculjak D, Butković-Soldo S, Mrden AM, Kondza G, TadzićR.Ultrasound evaluation of extracranial carotid artery lesions in Parkinsonian patients. 2010; 34 (3): 1081-5.

22. Alexa D., Constantinescu A, Baltag D, Ignat B, Bolbocean O, Popescu CD. Parkinson's disease and carotid intima-media thickness. 2014; 118 (1): 52.

23. Lee JM1, Park KW, Seo WK, Park MH, Han C, Jo I,Carotid intima-media thickness in Parkinson's disease., Ahn Jo S. 2007.

\section{Список Митературы:}

1. Scigliano G, Musicco M, Soliveri P. et al. Reduced risk factors for vascular disorders in Parkinson disease patients: a casecontrol study. Stroke. 2006; 37 (5): 1184-1188.

2. Reiss B, Siller K.A., Rahman M.M. et al. Cholesterol in neurologic disorders of the elderly: stroke and Alzheimer's disease. Neurobiology of Aging. 2004; 25 (8): 977-989.

3. Folstein M.F., Folstein S.E., McHugh P.R. Mini-mental status $J$ Psychiatr Res. 1975; 12: 189-196.

4. Lau L.M., Breteler M.M.B. Epidemiology of Parkinson's disease. Lancet Neurol. 2006; 5: 525-535

5. Huang X, Alonso A, Guo X et al. Statins, plasma cholesterol, and risk of Parkinson's disease: A prospective study. Mov Disord. 2015; 30: 552-559.

6. Hu G, Antikainen R, Jousilahti P et al. Total cholesterol and the risk of Parkinson disease. Neurology.2008; 70: 1972-1979.

7. Василенко А.Ф., Шамуров Ю.С. Аипидный обмен при болезни Паркинсона. Журнал неврологии и психиатрии ии.С.С.Корсакова. 2012; 112 (7): 65-67.

8. Stein J.H., Korcarz C.E., Hurst R.T., et al. Use of carotid ultrasound to identify subclinical vascular disease and evaluate cardiovascular disease risk: a consensus statement from the American Society of Ehocardiography Carotid Intima-Media Thickness Task Force. Endorsed by the Society for Vascularmedicine. J. Am. Soc. Echocardiogr. 2008; 21: 93-111.

9. Киндяшова В.В., Тихомирова О.В., Зыбина Н.Н., Кожевни кова В.В, Васильев В.Н., Журнал Всероссийского иентр аэкстренной и радиационной медицины им. А.М. Никифорова МЧС России. 2014, 4: 53-56.

10. Pignoli P, Tremoli E, Poli A, et al. Intimal plus medial thickness of the arterial wall: a direct measurement with ultrasound imaging. Circulation 1986; 74: 1399-406.

11. Катамадзе Н.О., Берштейн А.А., Гришкин Ю.Н. Диагностика субклинического атеросклероза как элемент современной стратегии стратификаиии сердечно- сосудистого риска. Кардиоваскулярная терапия и профилактика. 2012; 11 (2): 76-84.

12. Жукова И.А., Жукова Н.Г., Ижболдина О.П., Никитина М.А., Алифирова В.М. Анализ методов оиенки обоняния у пациентов с болезнью Паркинсона. Журнал неврологии и психиатрии им. С.С. Корсакова. Выпуск 2, Неврология и психиатрия пожилого возраста, 2015. С.47-52

13. Гусев Е.И., Сквориова В.И. Ишемия головного мозга. М., Медииина, 2001. 328 с.

14. Макаров Н.С. , Спиридонова С.В., Никитина В.В., Воскресенская О.Н., Захарова Н.Б. Молекулярные маркеры повреждения эндотелия у паииентов с болезнью Паркинсо-
24. National recommendations: Cardiovascular prophylaxis. Appendix 2 to the journal "Cardiovascular Therapy and Prevention". 2011; 10 (6): 1-64 (in Russian).

25. Dolgova V.V., Menshikova V.V. Clinical laboratory diagnostics: national guidelines: in 2 T.-T1. Moscow., GEOTAR-Media, 2012. 928 p. (in Russian).

26. Nazarenko G.I., Kishkun A. Clinical evaluation of laboratory results. M., Medicine, 2000. P. 146-152 (in Russian).

27. De Lau L.M., Koudstaal P.J., Hofman A. et al. Serum cholesterol levels and the risk of Parkinson's disease. American Journal of Epidemiology. 2006; 164 (10): 998-1002.

на. Саратовский научно -медииинский журнал. 2006; 2 (3): 29-33.

15. Bar-On P, Rockenstein E, AdameA et al. Effects of the cholesterol-lowering compound methyl- $\beta$-cyclodextrin in models of asynucleinopathy. Journal of Neurochemistry. 2006; 98 (4): 1032 1045.

16. Гуторова Д.А., Васенина Е.Д., Васенина Е.Е, Аевин О.С. Является ли гиперлипидемия фрактором риска болезни Паркинсона? Журнал неврологии и психиатрии им. С.С. Корсакова. 2015; 115 (6).

17. Resveratrol preserves cerebrovascular density and cognitive function in aging mice Charlotte A. Oomen, EszterFarkas, Viktor Roman, Eline M. van der Beek, Paul G. M. Luiten and Peter Meerlo.

18. Аитвиненко И.В. Болезнь Паркинсона. М., Миклош, 2006. $216 \mathrm{c}$.

19. Голубев В.А., Аевин Я.И., Вейн А.М. Болезнь Паркинсона и синдром паркинсонизма. М., МЕДпресс, 1999. С. 41-48.

20. Крыжановский Г.Н., Карабань И.Н., Магаева С.В., Кучеряну В.Г., КарабаньН.В.Болезнь Паркинсона (этиология, патогенез, клиника, диагностика, лечение, профилактика). М., Медииина, 2002. 336 c.

21. Bradvica IS1, Janculjak D, Butković-Soldo S, Mrden AM, Kondza G, TadzićR.Ultrasound evaluation of extracranial carotid artery lesions in Parkinsonian patients. 2010; 34 (3): 1081-5.

22. Alexa D., Constantinescu A, Baltag D, Ignat B, Bolbocean O, Popescu CD. Parkinson's disease and carotid intima-media thickness. 2014; 118 (1): 52.

23. Lee JM1, Park KW, Seo WK, Park MH, Han C, Jo I,Carotid intima-media thickness in Parkinson's disease., Ahn Jo S. 2007. 24. Наииональные рекомендаиии: Кардиоваскулярная профилактика. Приложение $2 \kappa$ журналу "Кардиоваскулярная терапия и профилактикал. 2011; 10 (6): 1-64.

25. Долгова В.В., Меньшикова В.В. Клиническая лабораторная диагностика: национальное руководство: в 2 т.-T1. М., ГЭОТАР-Медиа, 2012. 928 с.

26. Назаренко Г. И., Кишкун А. Клиническая оценка результатов лабораторных исследований. М., Медииина, 2000. 146-152.

27. De Lau L.M., Koudstaal P.J., Hofman A. et al. Serum cholesterol levels and the risk of Parkinson's disease. American Journal of Epidemiology. 2006; 164 (10): 998-1002. 